STUDI

FRANCESI

\section{Studi Francesi}

Rivista quadrimestrale fondata da Franco Simone

160 (LIV | I) | 2010

II simbolismo. Nomi, aspetti, momenti. Studi in memoria di Ivos Margoni

\title{
Maureen Boulton, Burgundian Devotional Manuscripts: Philip the Good, in Courtly Arts and the Art of Courtliness
}

\section{Maria Colombo Timelli}

\section{OpenEdition}

\section{Journals}

Édition électronique

URL : http://journals.openedition.org/studifrancesi/7149

DOI : $10.4000 /$ studifrancesi.7149

ISSN : 2421-5856

Éditeur

Rosenberg \& Sellier

Édition imprimée

Date de publication : 1 avril 2010

Pagination : 128

ISSN : 0039-2944

Référence électronique

Maria Colombo Timelli, « Maureen Boulton, Burgundian Devotional Manuscripts: Philip the Good, in Courtly Arts and the Art of Courtliness », Studi Francesi [En ligne], 160 (LIV | I) | 2010, mis en ligne le 30 novembre 2015, consulté le 14 janvier 2021. URL : http://journals.openedition.org/studifrancesi/7149 ; DOI : https://doi.org/10.4000/studifrancesi.7149

Ce document a été généré automatiquement le 14 janvier 2021.

\section{(c) $(1) \Theta$}

Studi Francesi è distribuita con Licenza Creative Commons Attribuzione - Non commerciale - Non opere derivate 4.0 Internazionale. 


\title{
Maureen Boulton, Burgundian Devotional Manuscripts: Philip the Good, in Courtly Arts and the Art of Courtliness
}

\author{
Maria Colombo Timelli
}

\section{RÉFÉRENCE}

MAUREEN BOUlton, Burgundian Devotional Manuscripts: Philip the Good, in Courtly Arts and the Art of Courtliness (ed. by Keith BUSBY, Christopher KLEINHENZ), Cambridge, D.S. Brewer, 2006, pp. 259-274.

1 La «librairie» de Philippe le Bon, troisième duc de Bourgogne, était riche en œuvres de dévotion - livres d'heures, psautiers, bréviaires, vies de saints, traités liés au courant de la devotio moderna-ce qui contraste, apparemment, avec une vie et une morale certainement mondaines. L'analyse des manuscrits conservés et des traductions commanditées par le duc, entre autres à Jean Miélot, permet à M.B. d'affirmer que l'intérêt de Philippe ne portait pas uniquement sur la valeur artistique des manuscrits; au contraire, surtout pendant les vingt dernières années de sa vie, il manifesta un véritable intérêt pour la littérature religieuse, et notamment pour la prière individuelle et la méditation sur l'humanité du Christ. On trouvera en appendice la liste des mss. dévotionnels de Philippe le Bon, ainsi que celle des traductions exécutées par Miélot. 